\title{
EFFECT OF USING GINGER POWDER AS NATURAL FEED ADDITIVE ON PERFORMANCE AND CARCASS QUALITY OF BROILER CHICKS
}

\author{
SAFA M.A. ELTAZI
}

Faculty of Agriculture, Omdurman Islamic University, P.O. Box 382, Sudan.

E-Mail:safamohamedeltazi@yahoo.com

\section{ABSTRACT}

Received at: 22/3/2014

The effect of feeding broiler chicks diets containing different levels of ginger powder as natural feed additive on productive performance, carcass characteristics and economical efficiency was studied. A total of two hundred one-day old, unsexed (Ross-308) broiler chicks were randomly divided into four experimental groups. Each group was further subdivided into five replicates at the rate of ten chicks per

Accepted: 12/4/2014 pen in complete randomized design. The birds were fed with two basal diets (starter and finisher diets). The ginger powder (Zingiber officinale) was added to the basal diets at level $(0.0,1,1.5$ and $2.0 \%)$ resulting in four formulae respectively to groups $\mathrm{A}, \mathrm{B}, \mathrm{C}$ and $\mathrm{D}$ with group A serving as control group. The experimental diets were fed for 6-weeks duration. Health of the stock and performance parameters were recorded. At the end of the experiment, the birds were slaughtered, dressed then used for different parameters and economical evaluation were calculated. The results showed that, the diet with $1 \%$ ginger powder had significantly $(\mathrm{P}<0.05)$ heaviest body weight gain, higher feed intake, best feed conversion ratio, and highest dressing percentage with the highest percentage of commercial cuts (breast drumstick and thigh). The birds fed the control diet produced significantly $(\mathrm{P}<0.05)$ highest abdominal fat percentage. The mortality rate was not affected significantly by the inclusion of ginger powder in broiler diet. The highest profitability ratio (1.30) was obtained by the diet with $1 \%$ ginger powder. Inclusion of ginger powder at level $2 \%$ in broiler diet had adverse effect on growth performance.

Key words: Ginger powder, Feed additive, Broiler chicks.

\section{INTRODUCTION}

Feed additives are added to broiler diets to improve its productive performance by increasing growth rate, better feed conversion efficiency and greater livability in poultry birds. Spices as an additive in the diet of chickens is very common. Active principles of the plant or chemical compounds present in certain parts of the plant or the effect of therapeutic activity that companies them (Zhang et al., 2009). Spices and herbs can have many benefits for the health of broilers and functions such as antioxidation ability (Hui, 1996), antimicrobial activity (Dorman and Deans, 2000), enhancing digestion by stimulating endogenous enzymes (Brugalli, 2003). Ginger (Zingiber officinale) is a perennial plant which belongs to family Zingiberaceae. Ginger is widely used in many countries as a food spice and as a herbal remedy used (Chrubasik et al., 2005). The main important compounds in ginger are gingerol, gingerdiol and gingerdione which have the ability to stimulate digestive enzymes, affect the microbial activity and having anti-oxidative activity (Dieumou et al., 2009). Ginger have been reported to posses useful pharmacological potent chemical substances for use in poultry (Akhtar et al., 1984), this is due to its antioxidants, antibacterial, anti-inflammatory, antiseptic, anti-parasitic and immunomodulatory properties. Positive effect of ginger on blood circulation, gastric secretion, and enterokinesia were reported by Ali et al. (2008); Incharoen and Yamauchi (2009). In addition, ginger has been found to enhance digestive enzyme activities (Platel and Srinivasan, 1996, 2000).

The objective of this study was intended to gain more information about the effect of using ginger powder as natural feed additive on performance and carcass quality of broiler chicks.

\section{MATERIALS and METHODS}

A total of two hundred one-day old unsexed (Ross308) broiler chicks were randomly distributed into 4 groups of 50 chicks. Each group was further subdivided into 5 replicates with 10 chicks per each. The chicks of each replicate were housed in a pen (1 square meter) in an open-sided deep litter house. Slices of dried ginger (Zingiber officinale) purchased from local market and ground to fine powder then 
added to basal diets at the levels $(0.0,1,1.5$ and $2 \%)$ resulting in four formulae respectively to group A, B, $\mathrm{C}$ and $\mathrm{D}$ where group $\mathrm{A}$ serving as control group. All the experimental diets were formulated to meet the nutrient requirements of broiler chicks according to NRC (1994) which was formulated from the local feed ingredients commonly used for poultry feeding in the Sudan. The experimental diets were fed for 6weeks duration where two phases of feeding program involved in supplying starter (1-21 days of age) and finisher (22-42 days of age). Calculated analysis of the experimental basal diets was done according to feedstuff analysis outlined by Ellis (1981), while determined chemical analysis was conducted by the method of AOAC (1995). Formulation and proximate analysis and calculated analysis for the experimental basal diets are shown in Tables ( 1 and 2) respectively, while chemical composition of the super concentrate used in the basal diets and determined composition of ginger are shown in Table (3 and 4) respectively.
Feed and water were offered ad-libitum. The light was continuous throughout the experimental period. The performance of the experimental birds in term of feed intake, live weight gain and feed conversion ratio were recorded weekly. Health of the experimental stock and mortality rate were closely observed and recorded daily. At the end of $6^{\text {th }}$ week the experimental birds were individually weighed after overnight fast (except for water) then slaughtered without stunning. They were then scalded, manually plucked, washed and allowed to drain on wooden tables. Evisceration was performed by a ventral cut and visceral as well as thoracic organs were removed. After evisceration, internal organs (heart, liver and gizzard) were removed, weighed individually and expressed as percentage of slaughtered weight. Eviscerated carcasses were weighed and then chilled in a refrigerator for 24 hours at $4^{\circ} \mathrm{C}$. Cold carcasses were recorded.

Table 1: Formulation and proximate analysis of the experimental basal diets (percent as fed).

\begin{tabular}{|c|c|c|c|}
\hline & Ingredients (\%) & Starter diet & Finisher diet \\
\hline \multirow[t]{10}{*}{ A: } & Formulation: & & \\
\hline & Grain sorghum & 53.00 & 65.00 \\
\hline & Wheat bran & 7.00 & 5.00 \\
\hline & Groundnut meal & 12.00 & 11.00 \\
\hline & Sesame meal & 18.00 & 9.00 \\
\hline & Super concentrate & 5.00 & 5.00 \\
\hline & Oyster shell & 2.75 & 2.75 \\
\hline & Common salt & 0.25 & 0.25 \\
\hline & Vegetable oil (corn) & 2.00 & 2.00 \\
\hline & Total & 100 & 100 \\
\hline \multirow[t]{7}{*}{ B: } & Determined analysis & & \\
\hline & Dry matter & 96.00 & 94.30 \\
\hline & Crude protein (N\% x 6.25) & 23.28 & 20.00 \\
\hline & Ether extract & 5.59 & 6.72 \\
\hline & Crude fibre & 6.46 & 5.40 \\
\hline & Ash & 10.49 & 8.74 \\
\hline & Nitrogen free-extract & 50.18 & 53.44 \\
\hline
\end{tabular}


Assiut Vet. Med. J. Vol. 60 No. 141 April 2014

Table 2: Calculated analysis of the experimental diets dry matter basis (DM).

\begin{tabular}{|c|c|c|}
\hline Item & Starter diet & Finisher diet \\
\hline Metabolizable energy (Kcal $/ \mathrm{kg})$ & 2940 & 3027 \\
\hline Crude fat & 7.91 & 6.57 \\
\hline Crude protein & 23.12 & 20.09 \\
\hline Lysine & 1.13 & 1.03 \\
\hline Methionine & 0.53 & 0.44 \\
\hline Cystine & 0.36 & 0.29 \\
\hline Methionine + cystine & 0.89 & 0.73 \\
\hline Calcium & 1.14 & 0.97 \\
\hline Available phosphorus & 0.63 & 0.55 \\
\hline Caloric-protein ratio & 127 & 151 \\
\hline ME Kcal/kg: protein \% & & \\
\hline
\end{tabular}

Metabolizable energy: calculated according to Ellis (1981)

Table 3: Chemical composition of the super concentrate used in the basal diets formulation (Hendrix broiler concentrate).

\begin{tabular}{|c|c|}
\hline Metabolizable energy & $1900(\mathrm{Kcal} / \mathrm{kg})$ \\
\hline Crude protein & $32.00 \%$ \\
\hline Lysine & $11.00 \%$ \\
\hline Methionine & $2.80 \%$ \\
\hline Methionine + cystine & $2.25 \%$ \\
\hline Calcium & $8.00 \%$ \\
\hline Available phosphorus & $5.00 \%$ \\
\hline
\end{tabular}

Table 4: Determined proximate composition of ginger [dry matter (DM) basis].

\begin{tabular}{lc}
\hline \multicolumn{1}{c}{ Parameter } & Ginger \\
\hline Dry matter & 91.0 \\
\hline Crude protein $(\mathrm{N} \% \times$ 6.25) & 10.1 \\
\hline Ether extract & 3.2 \\
\hline Crude fibre & 18.3 \\
\hline Ash & 4.9 \\
\hline Nitrogen free-extract & 54.5 \\
\hline
\end{tabular}

All the slaughtered birds were used for dissection. The breast, thigh and drumstick of the left side of each carcass were dislocated, weighed and expressed as percentage of cold carcass weight. Taste panel was done for broiler's breast and thigh meat after wrapped individually in aluminum foil, and roasted in an electric oven at $175^{\circ} \mathrm{C}$ for 90 minutes. Ten taste panelists were used to score colour, flavour, tenderness and juiciness of the meat, according to the guidelines of Cross et al. (1978). Statistical analyses were made by analysis of variance for a completely randomized design, according to Steel and Torrie (1986).

\section{RESULTS}

The effect of feeding different levels of ginger powder on broiler's performance is shown in Table (5). Final body weight, body weight gain, total feed intake and feed conversion ratio were affected significantly $(\mathrm{P}<0.05)$ with the addition of ginger powder to broiler diets. The final body weight and body weight gain were significantly $(\mathrm{P}<0.05)$ increased by the addition of ginger powder in the broiler diet as compared to control group except the diet with $2 \%$ ginger powder which produced significantly the lowest of these values. The feed intake decreased significantly $(\mathrm{P}<0.05)$ with the increasing level of ginger powder in the diet. The diet with $2 \%$ ginger powder showed significantly $(\mathrm{P}<0.05)$ the lowest of these values. The feed conversion ratio was improved significantly $(\mathrm{P}<0.05)$ by the supplementation of ginger powder in the diet. The best feed conversion ratio was produced significantly $(\mathrm{P}<0.05)$ by the diet that supplemented by $1 \%$ ginger powder.

All chicks were apparently healthy and the mortality was not significantly affected by the experimental treatments. 
Table 5: The effect of feeding different level of ginger powder on performance of broiler chicks (1-42 days).

\begin{tabular}{lccccc}
\hline \multicolumn{1}{c}{ Parameter } & $\mathrm{A}$ & $\mathrm{B}$ & $\mathrm{C}$ & $\mathrm{D}$ & SEM \\
\hline Initial live weight (g/chick) & 45.20 & 45.52 & 45.20 & 45.33 & - \\
\hline Final live weight (g/chick) & $1833.00^{\mathrm{b}}$ & $1980.50^{\mathrm{a}}$ & $1936.75^{\mathrm{a}}$ & $1796.30^{\mathrm{c}}$ & 45.31 \\
\hline Body weigh gain (g/chick) & $1787.80^{\mathrm{b}}$ & $1934.98^{\mathrm{a}}$ & $1891.55^{\mathrm{a}}$ & $1750.97^{\mathrm{c}}$ & 42.81 \\
\hline Total feed intake (g/chick) & $3754.38^{\mathrm{a}}$ & $3715.16^{\mathrm{a}}$ & $3669.60^{\mathrm{b}}$ & $3466.92^{\mathrm{c}}$ & 53.85 \\
\hline Feed conversion ratio & $2.1^{\mathrm{a}}$ & $1.92^{\mathrm{D}}$ & $1.94^{\mathrm{C}}$ & $1.98^{\mathrm{b}}$ & 0.03 \\
\hline Mortality \% & 0.00 & 0.25 & 0.30 & 0.25 & $0.24^{\mathrm{NS}}$ \\
\hline
\end{tabular}

A: Control (without ginger powder)

B: $1.0 \%$ ginger powder

C: $1.5 \%$ ginger powder

D: $2.0 \%$ ginger powder

SEM: Standard error of the means

N.S. Not statistically significant $(\mathrm{P}>0.05)$

Means on the same raw with the same superscripts are not significantly different $(\mathrm{P}>0.05)$.

Table (6) shows the effect of feeding different levels of ginger powder on carcass characteristics of broilers. All the measured parameters were significantly $(\mathrm{P}<0.05)$ improved with the inclusion of ginger powder in broiler diets except the diet with $2 \%$ ginger powder. The diets with $1 \%$ and $1.5 \%$ ginger powder recorded significantly $(\mathrm{P}<0.05)$ the highest hot and cold dressing percentages and highest breast, drumstick and thigh percentages while the lowest percentages of these values were recorded by the diet with $2 \%$ ginger powder.

Table 6: Mean values for the dressing carcass percentages and commercial cut of broiler carcasses.

\begin{tabular}{llllll}
\hline \multicolumn{1}{c}{ Parameters } & A & B & C & D & SEM \\
\hline Hot dressing percentages & $68.25^{\mathrm{b}}$ & $70.02^{\mathrm{a}}$ & $69.81^{\mathrm{a}}$ & $67.62^{\mathrm{c}}$ & 0.15 \\
\hline Cold dressing percentage & $68.01^{\mathrm{b}}$ & $69.03^{\mathrm{a}}$ & $68.82^{\mathrm{a}}$ & $67.06^{\mathrm{c}}$ & 0.11 \\
\hline Breast as \% of cold carcass & $25.53^{\mathrm{b}}$ & $26.01^{\mathrm{a}}$ & $25.91^{\mathrm{a}}$ & $24.03^{\mathrm{c}}$ & 1.26 \\
\hline Drumstick as \% of cold carcass & $15.00^{\mathrm{b}}$ & $16.03^{\mathrm{a}}$ & $15.91^{\mathrm{a}}$ & $14.82^{\mathrm{c}}$ & 0.22 \\
\hline Thigh as \% of cold carcass & $15.75^{\mathrm{b}}$ & $16.53^{\mathrm{a}}$ & $16.26^{\mathrm{a}}$ & $15.09^{\mathrm{c}}$ & 0.20 \\
\hline
\end{tabular}

Means on the same raw with the same superscripts are not significantly different $(\mathrm{P}>0.05)$.

Table (7) shows the effect of feeding different levels of ginger powder on the non-carcass components as the percentage of body weight. All the measured parameters were significantly affected $(\mathrm{P}<0.05)$ by the addition of ginger powder to the experimental diets except the heart percentage. The adding of ginger powder to broiler diets significantly $(\mathrm{P}<0.05)$ decrease the percentage of abdominal fat, liver and gizzard. The control diet showed significantly $(\mathrm{P}<0.05)$ the highest abdominal fat, liver and gizzard percentages while the diets supplemented with ginger powder significantly $(\mathrm{P}<0.05)$ produced the lowest values.

Table 7: Body weight and organ proportions of broiler chickens.

\begin{tabular}{lccccc}
\hline \multicolumn{1}{c}{ Parameters } & $\mathrm{A}$ & $\mathrm{B}$ & $\mathrm{C}$ & $\mathrm{D}$ & SEM \\
\hline Final body weight (g/chick) & $1833.00^{\mathrm{b}}$ & $1980.50^{\mathrm{a}}$ & $1936.75^{\mathrm{a}}$ & $1796.30^{\mathrm{c}}$ & 45.31 \\
\hline Abdominal fat as \% of body weight & $2.35^{\mathrm{a}}$ & $1.92^{\mathrm{b}}$ & $1.91^{\mathrm{b}}$ & $1.90^{\mathrm{b}}$ & 0.017 \\
\hline Liver as \% of body weight & $2.9^{\mathrm{a}}$ & $2.20^{\mathrm{b}}$ & $2.18^{\mathrm{b}}$ & $2.15^{\mathrm{b}}$ & 0.10 \\
\hline Heart as \% of body weight & 0.55 & 0.52 & 0.54 & 0.53 & $0.011^{\mathrm{Ns}}$ \\
\hline Gizzard as \% of body weight & $2.92^{\mathrm{a}}$ & $2.29^{\mathrm{b}}$ & $2.25^{\mathrm{b}}$ & $2.10^{\mathrm{b}}$ & 0.01 \\
\hline
\end{tabular}

Means on the same raw with the same superscripts are not significantly different $(\mathrm{P}>0.05)$.

Table (8) shows the effect of dietary treatment on subjective scores for breast and thigh of broiler meat. The values of tenderness, juiciness, flavour and colour did not differ significantly $(\mathrm{P}<0.05)$ among the dietary treatments and the score given for all attributes are above moderate acceptability level. 
Assiut Vet. Med. J. Vol. 60 No. 141 April 2014

Table 8: Subjective scores for the breast and thigh of broiler meat.

\begin{tabular}{llllll}
\hline \multicolumn{1}{c}{ Parameters } & $\mathrm{A}$ & $\mathrm{B}$ & $\mathrm{C}$ & $\mathrm{D}$ & SEM \\
\hline Tenderness & & & & & \\
\hline Thigh & 5.62 & 5.35 & 5.48 & 5.22 & $0.04^{\mathrm{NS}}$ \\
\hline Breast & 5.34 & 5.20 & 5.21 & 5.01 & $0.03^{\mathrm{NS}}$ \\
\hline Juiciness & & & & & \\
\hline Thigh & 5.52 & 5.70 & 5.55 & 5.46 & $0.03^{\mathrm{NS}}$ \\
\hline Breast & 5.43 & 5.61 & 5.43 & 5.31 & $0.02^{\mathrm{NS}}$ \\
\hline Flavour & & & & & $0.03^{\mathrm{NS}}$ \\
\hline Thigh & 5.51 & 5.36 & 5.29 & 5.58 & $0.03^{\mathrm{NS}}$ \\
\hline Breast & 5.62 & 5.75 & 5.60 & 5.42 & \\
\hline Colour & & & & & $0.04^{\mathrm{NS}}$ \\
\hline Thigh & 5.29 & 5.51 & 5.60 & 5.42 & $0.03^{\mathrm{NS}}$ \\
\hline Breast & 5.35 & 5.40 & 5.22 & 5.35 &
\end{tabular}

Means on the same raw with the same superscripts are not significantly different $(\mathrm{P}>0.05)$.

Table (9) shows calculation of total cost, revenues and net profit for the experimental groups. The results obtained from the economic study indicated that, treatment (B) with $1 \%$ ginger powder showed the highest profitability ratio (1.3) while the lowest ratio was produced by treatment (D) with $2 \%$ ginger powder $(0.89)$ as compared to control group.

Table 9: Total cost, revenues and net profit of broiler chicks fed on different levels of garlic powder.

\begin{tabular}{clcccc}
\hline & Item & A & B & C & D \\
\hline Cost(SDG) & & & & & \\
\hline & Chick purchase & 6.00 & 6.00 & 6.00 & 6.00 \\
\hline & Management & 4.00 & 4.00 & 4.00 & 4.00 \\
\hline & Feed & 11.70 & 11.72 & 11.79 & 11.82 \\
\hline & Total cost & 21.70 & 21.72 & 21.79 & 21.82 \\
\hline Revenues & & & & & \\
\hline & Average eviscerated carcass weight $(\mathrm{kg})$ & 1.25 & 1.39 & 1.35 & 1.21 \\
\hline & Price $($ SDG/kg) & 23 & 23 & 23 & 23 \\
\hline & Total revenues & 28.75 & 31.97 & 31.05 & 27.94 \\
\hline Net profit & & & & \\
\hline & & 28.75 & 31.97 & 31.05 & 27.94 \\
\hline & Total revenues & 21.70 & 21.72 & 21.79 & 21.82 \\
\hline & Total cost & 7.05 & 10.25 & 9.26 & 6.12 \\
\hline & Net profit/bird & 5.64 & 7.37 & 6.86 & 5.06 \\
\hline & Net profit/kg meat & 1.00 & 1.30 & 1.22 & 0.89 \\
\hline & Profitability ratio/kg meat & & & &
\end{tabular}

\section{DISCUSSION}

The effect of feeding graded levels of ginger powder on productive performance of broiler is shown in Table (5). Treatment effect on final body weight, body weight gain, total feed intake and feed conversion ratio was significant $(\mathrm{P}<0.05)$. The inclusion of ginger powder in diet of broiler significantly $(\mathrm{P}<0.05)$ enhanced the body weight and the bodyweight gain as compared to the control group with the exception for the diet with $2 \%$ ginger powder which showed significantly $(\mathrm{P}<0.05)$ adverse effect. The treatments with ( 1 and $1.5 \%$ ) ginger powder showed the highest weight gain as compared to control group. The improvement in body weight gain in the levels ( 1 and $1.5 \%$ ) ginger powder could be attributed to the fact that herbal plant may provide some compounds that enhance digestion and absorption of some nutrients in these diets which leading to improve the growth of birds. This result was in line with the finding of Igbal et al. (2011); Demir et al. (2003) who reported that there is an increase in body weight by using ginger in broiler diets. Some experts reported that red ginger has characteristics as stimulant for feed digestion and conversion which increase body weight gain. On the other hand, the depression on body weight in the diet with $2 \%$ ginger powder could be explained by the fact that some scientifics evidence demonstrated that many of herbal plants have medical properties that alleviate symptom and may prevent diseases and also high use of them may cause poisoning due to its strong bitter taste and reduce feed intake which could be leading to reduction in body weight (Hosseini, 
2011; Ficker et al. 2003). The result coincided with the finding of Herati and Marjuki (2011) who mentioned that, increase ginger in the ration up to $2 \%$ showed lower total weight gain. This was contrary to the findings of Garcia et al. (2007); Ghazaiah et al. (2007) and Tollba et al. (2007) who observed no difference in bodyweight gain in broilers fed with ginger and pepper extract for a period of six weeks. In addition Onimisi et al. (2005) and Ademola et al. (2009) observed that ginger increased body weight when included up to $2 \%$ level in the diet. Similarly, Al-Homidan (2005) found increased in weight gain of broilers when fed $2 \%$ and $6 \%$ ginger.

The feed intake significantly $(\mathrm{P}<0.05)$ tended to decease with increasing the level of ginger powder in the diets of broiler as compared to control diet. The lowest feed intake was significantly $(\mathrm{P}<0.05)$ found by the birds fed with $2 \%$ level of ginger powder. These results are in agreement with those reported by Zomrawi et al. (2013); Herawati (2006) who mentioned that, birds fed diet with $1.5-2.0 \%$ ginger consumed less amount of feed. Similar result was obtained by Herawati (2010) who reported that, broiler fed $2 \%$ dried supplementary red ginger meal had significantly lower feed intake than those fed on the control diet. The results coincided with the finding of Herati and Marjuki (2011) who mentioned that increase ginger in the ration up to $2 \%$ showed lower feed intake. This was contrary to the finding of Doley et al. (2009) who observed no difference in feed intake by broilers fed with ginger extract for a period of six weeks.

The feed conversion ratio was affected significantly $(\mathrm{P}<0.05)$ by the experimental diets. There was a significant $(\mathrm{P}<0.05)$ improvement in the feed conversion ratio for the birds fed diets supplemented with ginger powder. The best feed conversion ratio was significantly $(\mathrm{P}<0.05)$ obtained by the diet with $1 \%$ ginger powder. The better feed conversion ratio can be attributed to the anti-bacterial properties of the ginger powder which resulted in better absorption of the nutrients in the gut and finally leading to improvement in feed conversion ratio. These results are consistent with the finding of Herawati (2006); Tollba (2003); Herawati (2010); Moorthy et al. (2009) and Onimisi et al. (2005) they illustrated that birds fed with diets containing ginger up to $2 \%$ recorded better feed conversion ratio than unsupplemented ones. The positive effect of ginger powder in broiler diets on the final body weight and body weight gain and feed conversion ratio can be explained by the fact that, ginger have medical and chemical properties responsible for taste, the most noteworthy being ginerol and shagaol. It has antibacterial and anti-inflammatory actions (Zomrawi, 2012). Due to the active ingredients that found in ginger formation of more stable intestinal flora and improved feed conversion efficiency in consequence of better digestion (Tekeli, 2007). Treatment effect on mortality rate was not significant. The birds died in the experiment were not related to experimental treatments.

As shown in Table (6) the hot and cold dressing percentages were significantly $(\mathrm{P}<0.05)$ affected by the addition of ginger powder to the diets of broiler. The diets with 1 and $1.5 \%$ ginger powder produced significantly $(\mathrm{P}<0.05)$ the highest percentages of hot and cold dressing carcasses while the lowest percentages were significantly $(\mathrm{P}<0.05)$ produced by diet $2 \%$ ginger powder as compared to control diet. The higher dressing percentages of birds fed with $1 \%$ and $1.5 \%$ ginger powder diets and those obtained lower percentage for group fed with $2 \%$ ginger powder may be attributed to the coincided effect of these levels in feed intake and weight gain. These results are in line with the finding of Zomrawi (2013) who found higher dressing percentage of birds received $1 \%$ ginger root powder diet lower percentage for group fed $2 \%$ ginger root powder diet. In contrast, Zomrawi et al. (2012) found, no significant differences $(\mathrm{P}>0.05)$ were observed in dressing percentage among the birds that fed with different levels of ginger root powder $(0.0 \%, 0.5 \%, 1 \%$ and $1.5 \%)$. The percentages of commercial cuts (breast, drumstick and thigh) showed significant $(\mathrm{P}<0.05)$ improvement with the inclusion of ginger powder in the broiler diets with exception of the diet with the $2 \%$ ginger powder. These results are in line with the findings of Alcicek et al. (2004); Tollba et al. (2007), Ademola et al. (2009) and Javed et al. (2009) who stated that, carcass characteristics improved in broilers fed different levels of powder aqueous extract of ginger from 1-42 days of age. In contrast, El-Deck et al. (2002) and Moorthy et al. (2009) observed no significant effect on carcass characteristics of broilers fed with different levels ginger power and extract of ginger up to six weeks of age.

As shown in Table (7), the inclusion of ginger powder in the broiler diets significantly $(\mathrm{P}<0.05)$ affected the percentages of non-carcass components (abdominal fat, liver and gizzard) except the heart percentage. Generally, it seems that, the higher percentage of ginger powder in the diets, the lower percentages of the abdominal fat, liver and gizzard compared to control group. The reduction in the percentage of abdominal fat for the diets supplemented with ginger powder may be attributed to the action of ginger which have been reported to posses lipid lowering effects (Sharma et al., 1996). Similarly, several studies showed that, the addition of ginger and its essential oils to broiler diet as growth promoters reduced significantly the abdominal fat of the chickens (Rafiee et al., 2013; Valiollahi et al., 2014). In addition Ademola et al. (2009) stated that, ginger could be used as antilipidemic agents in broiler diets to lower abdominal fat pad. 
As shown in the Table (8) no significant differences were observed between all treatment groups in subjective meat quality attributes (colour, flavour, juiciness and tenderness) of the breast and thigh meat. All the scores being at above moderate values.

As shown in Table (9), the economical evaluation of the experimental diets indicated that the diet with $1 \%$ level of ginger powder showed the highest profitability ratio (1.3) while the diet with $2 \%$ level of ginger powder showed the lowest ration (0.89). This might be due to the highest and lowest returns of the weight gains recorded by these groups of chicks respectively.

It could be concluded that the incorporation of ginger in broiler diet as feed additive at $1 \%$ level significantly enhanced growth and productive performance of broiler chicks.

\section{REFERENCES}

Ademola, S.G.; Farinu, G. and Babatunde, G.M. (2009): Serum lipid, growth and hematological parameters of broilers fed garlic, ginger and their mixtures. World J. Agric. Sci., 5: 99-104.

Akhtar, M.S.; Afzal, H. and Chaudry, F. (1984): Preliminary in vitro antibacterial screening of Bakain, and Zarisk against salmonella Medicose, 9: 6-7.

Alcicek, A.; Bozkurt, M. and Cabuk, M. (2004): The effect of mixture of herbal essential oils, an organic acid or a probiotic on broiler performance. South Afr. J. Anim. Sci., 34(4): 217-222.

Al-Homidan, A.A. (2005): Efficiency of using different sources and levels of Allium cepa, Allium sativum and Zingiber officinale on broiler chicks performance. Saudi Journal of Biological Science, 12 (2): 96-102.

Ali, B.H.; Blunden, G.; Tanira, M.O. and Nemmar, A. (2008): $\quad$ Some phytochemical, pharmacological and toxicological properties of ginger (Zingiber officinale Roscoe): A review of recent research. Feed Chem. Toxico., 46: 409-420.

$A O A C$ (1995): Official methods of analytical $\left(13^{\text {th }}\right.$ ed). Association of Official Analytical Chemists, Washington, D.C., USA.

Brugalli, I. (2003): Alimentacao alternativa: An utilizacao de fitoterapicos ou nutraceuticos comomoduladores da imunidade e desempenho animal. Anais do Simposio sobre Manejo e Nutri cao de Aves e Suinos; Campinas, Sao Paulo. Brasil. Campainas: (BNA,), pp. 167-182.

Chrubasik, S.M.H.; Pittler and Roufogalis, B.D. (2005): Zingiberis rhizome: A comperhensive review on the ginger effect and efficacy profiles. Phytomedicine, 12: 684-701.

Cross, H.R.; Moen, R. and Stanfield, M.S. (1978): Training and testing of judges for sensory analysis of meat quality. Food Technology, 32-48.

Demir, E.; Sarica, S.; Ozcan, M.A. and Suicmez, M. (2003): The use of natural feed additives as alternative for an antibiotic growth promoter in broiler diets Br., Poultry Sci., 44: 44-45.

Dieumou, F.E.; Teguia, A.; Kuiate, J.R.; Tamokou, J.D.; Fonge, N.B. and Donogmo, M.C. (2009): Effect of ginger (Zingiber officinale) and garlic (Allium sativum) essential oils on growth performance and gut microbial population of broiler chicks. Livestock Research for Rural Development, 21 (8): 21-33.

Doley, S.; Cupta, J.J. and Reddy, P.B. (2009): Effect of supplementation of ginger, garlic and turmeric in broiler chicken. Indian Vet. J., 86(6): 644-645.

Dorman, H.J.D. and Deans, S.G. (2000): Antimicrobial agents from plants: Antibacterial activity of plant volatile oils. J. appl. Microbiol., 88: 308-316.

El-Deek, A.A.; Attia, Y.A. and Hannfy, M.M. (2002): Effect of anise (Pimpinella anisum), ginger (Zingiber officinal roscoe) and fennel (Foeniculum vulgare) and their mixture on performance of broilers. Arch. Geflugelk, 67(2): 92-96.

Ellis, N. (1981): The nutrient composition of Sudanese animal feeds. Bulletin, 1: Northern and Central Sudan, Central Animal Nutrition Research Laboratory, Kuku Research Centre, Khartoum North, Sudan.

Ficker, C.F.; Smith, M.L.; Leaman, D.L.; Irawati, C. and Amason, J.T. (2003): Inhibition of human pathogenic fungi by member of Zingiberaceae used by Kenyah Indonesian borneo. J. Ethnopharmacol., 85: 289-293.

Garcia, V.P.; Catala-gregori, P.; Hernandez, F.; Megias, M.D. and Marid, J. (2007): Effect of formic acid and plant extracts on growth, nutrient digestibility, intestine mucosa morphology and meat yield of broilers. J. Appl. Poult. Res., 16: 555-562.

Ghazaiah, A.A.; El-Hakim, A.S. and Refaie, A.M. (2007): Response of broiler chicks to some dietary growth promoters throughout different growth periods. Egypt. Poult. Sci., J. 27: 53-57.

Herati and Marjuki (2011): Effect of feeding red ginger as phytobiotic on broiler slaughter weight and meat quality. Int. J. Poultry Sci., 10: $12-983-986$.

Herawati, (2006): Effect of red ginger (Zingiber officinale Rosc) phytobiotic addition to the broiler performance and blood profile. 
Pengaruh Penambahan Fitobiotik Jahe Merah, 14: 142-173

Herawati, (2010): The effect of feeding red ginger as phytobiotic on body weight gain, feed conversion and internal organs condition to broiler. Int. J. Poult. Sci., 9: 963-967.

Hosseini, M.N. (2011): Comparison of using different level of black pepper with probiotic on performance and serum composition on broilers chickens. Journal of Basic and applied Science Research, 11: 2425-2428.

Hui, Y.H. (1996): Oleoresins and essential oils. In: Hui, YH, editor. Bailey's industrial oil and fat products. New York, Wiley-Interscience Publication, Cap. 6. pp: 145-153.

Iqbal, Z.; Nadeem, Q.K.; Khan, M.N.; Akhtar, M.S. and Waraich, F.N. (2011): In vitro anthelmintic activity of Allium sativum, Zingiber officinale, Curcurbita mexicana and Ficus religiosa. International Journal of Agriculture biology, 3: 454-457.

Incharoen, T. and Yamauchi, K. (2009): Production performance, egg quality and intestinal histology in laying hens fed dietary dried fermented ginger. Poult. Sci., 8(11) 1078-1085.

Javed, M.; Durrani, F.R.; Hafeez, A.; Khan, R.U. and Ahmad, I. (2009): Effect of aqueous extract of plant mixture on carcass quality of broiler chicks. ARPN Journal of Agricutlure and Biological Science, 4(1): 37-40.

Moorthy, M.; Ravi, S.; Ravikumar, M.; Viswanathan, K. and Edwin, S.C. (2009): Ginger, pepper and curry leaf powder as feed additives in broiler diet. Int. J. Poult. Sci., 8(8): 779-782.

NRC, National Research Council (1994): Nutrient requirements of poultry $\left(9^{\text {th }}\right.$ Rev. ed) National Academy Press, Washington, D.C., USA.

Onimisi, P.A.; Dafwang, I.I. and Omage, J.J. (2005): Growth performance and water consumption pattern of broiler chicks fed graded levels of ginger waste meal. J. Agric., Forestry and Social Sci., 3: 113-119.

Platel, K. and Srinivasan, K. (1996): Influence of dietary spices or their active principles on digestive enzymes of small intestinal mucosa in rat. Int. J. Food Sci. Nutr., 47: 55-59.

Platel, K. and Srinivasan, K. (2000): Influence of dietary spices and their active principles on pancreatic digestive enzymes in Albino rats. Nahrung, 44(1): 42-46.

Rafiee, A.; Rahimian, Y.; Zamani, F. and Asgarian, F. (2013): Effect of use ginger (Zingiber officinale) and thymus (Thymus vulgaris) extract on performance and some hematological parameters on broiler chicks.
Sci. Agri. 4(1): 20-25.

Sharma, I.; Gusain, D. and Dixit, V.P. (1996): Hypolipidemic and antiatherosclerotic effects of Zingiber officinale in cholesterol fed rabbits, Phyto. Res., 10: 517-518.

Steel, R.G.D. and Torrie, J.H. (1986): Principles and procedures of statistics: A Biometrical Approach ( $2^{\text {nd }}$ ed). McGraw Hill Book company, Inc., NY, USA.

Tekeli, A. (2007): Potential use of plant extracts and propolis to be natural growth promoter in broiler chick's diets $\mathrm{Ph}$.D. Thesis, University of Cukurova Institute of Natural and Applied, Department of Animal Science, Adana.

Tollba, A.A. (2003): Using some natural additives to improve physiological and productive performance of broiler chicks under high temperature conditions. 1- Thyme (|Thymus vulgaris L) or fennel (Foeniculum vulgaris L). Egypt Poult. Sci. J. 23: 313-326.

Tollba, A.A.; Azouz, H.M.M. and Abd-Samad, M.H. (2007): Antioxidants supplementation to diet of Egyptian chicken under different environmental conditions. 2. The growth during cold winter stress. Egyptian Poutlry Science J., 27: 727-748.

Valiollahi, M.R.; Rahimian, Y.; Miri, Y. and Rafiee, A. (2013): Effect use ginger (Zingiber officinale), black pepper (Piper nigrum L) powders on performance, some blood parameters and antibody titer against new castle vaccine on broiler chicks. Scholarly Journal of Agriculture Science 3(12): 535-540.

Zhang, G.F.; Yang, Z.B.; Wang, Y.; Yang, W.R.; Jiang, S.Z. and Gai, G.S. (2009): Effects of ginger root (Zingiber officinale) processed to different particle size on growth performance, antioxidant status, and serum metabolites of broiler chickens. Poult. Sci., 88: 2159-2166.

Zomrawi, W.B.; Abdel Atti, K.A.A.; Dousa, B.M. and Mahala, A.G. (2012): The effect of ginger root powder (Zinger officinale) supplementation on broiler chicks performance, blood and serum constituents. Online Journal of animal and Feed Research, 6: 457-460.

Zomrawi, W.B.; Abdel Atti, K.A.A.; Dousa, B.M. and Mahala, A.G. (2013): The effect of dietary ginger root powder (Zingiber officinale) on broiler chicks' performance, carcass characteristics and serum constituents. Journal of Animal Science Advances, 3: 42-47. 


\section{اثز استخدام مسحوق الزنجبيل كاضافة علفية طبيعية على الأداء وخصائص الذبيح فى الاجاج اللاحم \\ صفاء محمد عبد الوهاب التازى \\ E-Mail:safamohamedeltazi@yahoo.com}

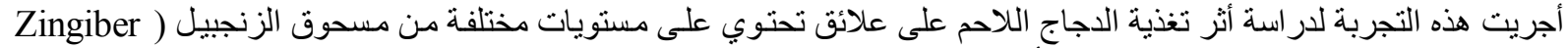

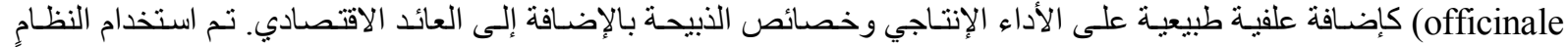

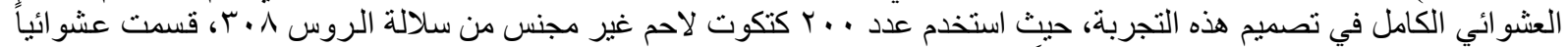

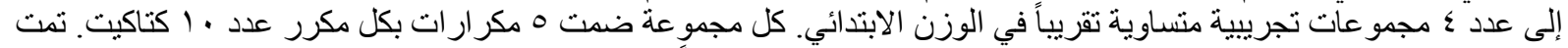

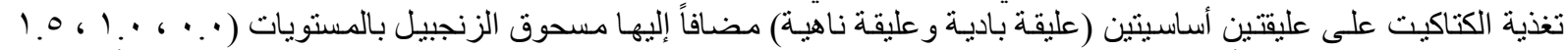

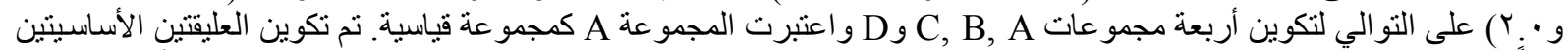

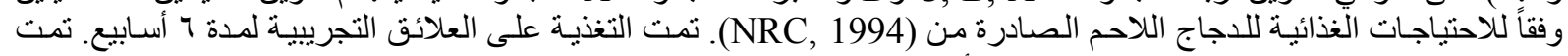

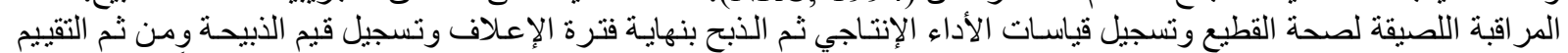

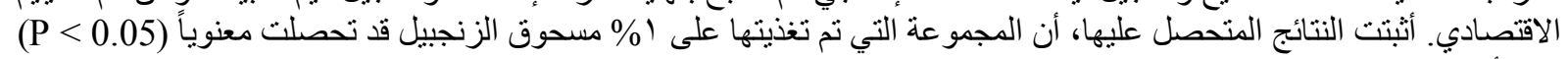

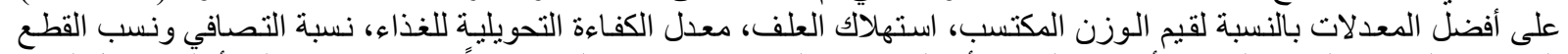

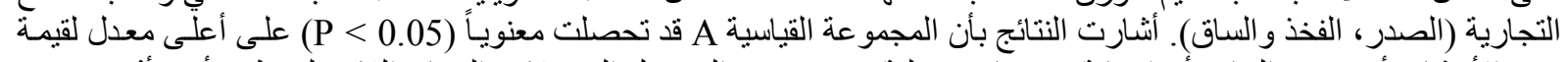

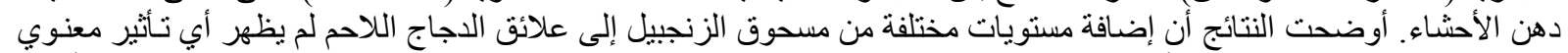
(P> $>0.05)$

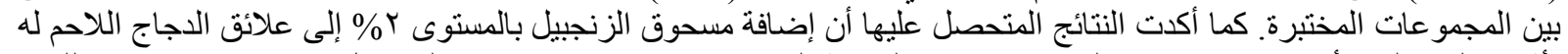

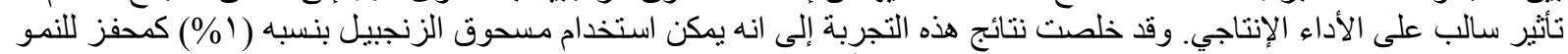

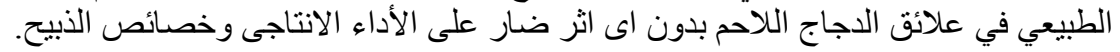

